Download

UDC 911.3

https://doi.org/10.17

721/2308-135X.2020.57.50-57

Kravets Taras Myroslavovych,

Candidate Of Geographical Sciences National Academy of the Army named after Hetman Sahaidachny, Lviv, Ukraine, e-mail: taras-kravets@ukr.net

\title{
SOCIO-GEOGRAPHICAL ESSENCE OF THE MILITARY SPHERE OF UKRAINE
}

The purpose of the article is to analyze the existing approaches to understanding the terms military sphere, military-industrial complex, defense-industrial complex, security and defense sector, military sector, determining the positioning of the military sphere and its position relative to other natural-geographical areas, joints and overlaps, identification of its functions and problems that interfere with proper functioning. Development of directions and prospects for the development of the military sphere and the Armed Forces of Ukraine in general.

Method. The research was conducted on the basis of the analysis of available literature sources on this topic and the application of a spherical approach to the analysis of the positioning of the military sphere and the definition of its components. The available domestic and foreign literary sources and the ratio of these concepts within this literature are studied.

Results. Theoretical and methodological problems of comparing concepts related to the military sphere and their interchangeability and interconnectedness are studied. The scheme of correlation of concepts of military sphere, defense-industrial complex and military-industrial complex is offered. Based on the spherical approach, we propose a scheme of the military sphere, which we consider as a sphere formed within the geosphere at the junction of social 
and natural spheres, at the intersection of demographic, informational, spiritual, environmental, technical, economic, political and social spheres. Within each oblast forming the sphere, three main sectors with the greatest influence on the military sphere are singled out. Six main functions of the sphere are singled out and arranged in order of importance on the basis of the proposed scheme.

Scientific novelty. The need for this study is due to the fact that despite the fact that since 2014 and to date, fighting has been going on in the east of our country, in many universities the discipline of military geography and related disciplines is being stolen, the term military sphere has not been proposed. clear positioning of the military sphere among other social spheres. To date, the functions performed by the military sphere and the factors contributing to the improvement and development of this sphere have not been determined, which is what led to the implementation of this study.

Practical meaning. Based on modeling and analysis, the main areas that affect the military sphere as such and to what extent are identified, the areas of greatest influence and sectors of influence within the regions are identified. The functions of the military sphere and the main factors influencing its development and transformation are highlighted, as well as what measures need to be implemented to improve the situation. The results of the research are developed for planning by the state structures of the program of development of the military sphere and for teaching the discipline "Military Geography". The geographical features of the military sphere are singled out, to which the greatest attention should be paid when analyzing the transformation of the military sphere.

Key words: military sphere, military-industrial complex, defense-industrial complex, defense capability, military potential.

References:

1. ATO in numbers. URL: https: // ru. espreso.tv/article/2017/04/14/ 
2. Law of Ukraine "On Defense of Ukraine" (Vidomosti Verkhovnoi Rady Ukrainy (VVR), 1992, №9, p. 106).

3. On improving the training of the Armed Forces of Ukraine (Concept of improving the training of the Armed Forces of Ukraine): Order of the Minister of Defense of Ukraine dated 25.10.2012. - Kyiv: Ministry of Defense of Ukraine, 2012. - 99699. - 18 p.

4. Pasichko V. Defense capability of the state: theoretical foundations of system research / [Electronic resource.] $\square$ Access mode: http // archive.nbuv.gov.ua / portal / soc_gum / pone / 2008_2 / PDF / Pasichko.pdf /

5. Military capability / [Electronic resource.] $\square$ Access mode: http // en.wikipedia.org/wiki/ Military_capability.

6. On the Armed Forces of Ukraine: Law of Ukraine of 2000 // Bulletin of the Verkhovna Rada of Ukraine. - 2000. - № 3. - Ст. 17. - 84 p. 
7. Pavlenkov AF Dictionary of foreign words included in the Russian language / A. F. Pavlenkov. - 2nd ed. - St. Petersburg, 1907. - 370 p.

8. Sector of security and defense of Ukraine: strategic leadership and military management: monograph / Saganyuk FV, Frolov VS, Pavlenko VI etc.; for order. Doctor of Military Sciences, Prof. I.S. Rusnaka. K .: Central Committee of the Ministry of Defense and General Staff of the Armed Forces of Ukraine, 2018. 230 p.

9. .Dictionary-reference book on economic geography. Grades 9-10 / TV Bulicheva, KO Butkalyuk, TA Hryniuk and others. For science. ed. VG Shchabelska. - H .: Type. Osnova group, 2004. - $112 \mathrm{p}$.

10. Personnel Processing (In-, Out-, Soldier Readiness, Mobilization, and Deployment Processing). - Washington: Headquarters Department of the Army, 2003. - 96 p.

Надійшла до редколегії 25.09.2020 
